\title{
A multimetric index based on fish fauna for the evaluation of the biotic integrity of streams at a mesohabitat scale
}

\author{
Índice multimétrico com base na fauna de peixes para avaliação da \\ integridade biótica de riachos em escala de meso-hábitat
}

Lilian Casatti ${ }^{1}$ and Fabrício Barreto Teresa ${ }^{2}$

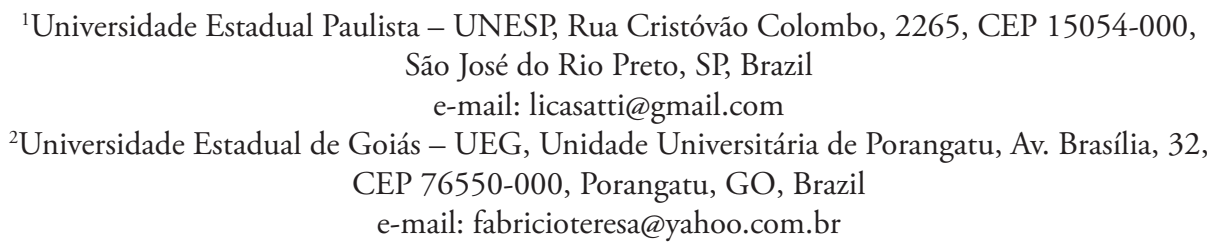

\begin{abstract}
Aim: In this study, we evaluated the ability of the Index of Biotic Integrity (IBI), based on fish fauna, to discriminate between reference streams and degraded streams at a mesohabitat scale. Methods: We sampled the ichthyofauna of 96 mesohabitats (runs, riffles and pools) with electrofishing gear in six streams (three reference and three degraded) of comparable volume, width, and depth. Twelve attributes were tested separately for different mesohabitat types. Results: Ten of the metrics tested were used to obtain the IBI for runs, six for riffles and ten for pools. The IBI indicated poor conditions for runs and riffles and very poor conditions for pools. Conclusions: These results indicate that the IBI may be useful for distinguishing among environments with contrasting conservation status at a mesohabitat scale. Differences were obtained not only in the sets of metrics valid for each mesohabitat but also in the final scores and rankings of the mesohabitat types assessed. These results emphasize the importance of considering the structural and biological variability of aquatic environments to capture the significance of losses of integrity due to human influence.
\end{abstract}

Keywords: ichthyofauna, habitat quality, conservation, IBI, biological monitoring.

Resumo: Objetivo: Neste estudo avaliamos se o Índice de Integridade Biótica (IBI) elaborado com base na ictiofauna é capaz de discriminar locais referência dos degradados em uma escala de meso-hábitat. Métodos: A ictiofauna de 96 meso-hábitats (corredores, corredeiras e poços) foi amostrada em seis riachos (três referência e três degradados) de volume, largura e profundidade comparáveis, por meio de pesca elétrica. Doze atributos biológicos foram testados, considerando os meso-hábitats separadamente. Resultados: Dez métricas compuseram o IBI para corredores, seis para corredeiras e dez para poços, indicando condiçôes pobres para corredores e corredeiras e muito pobres para poços. Conclusóes: Esses resultados indicam que o IBI aplicado em uma escala de meso-hábitat pode representar uma ferramenta útil para discriminar ambientes em estado de conservaçáo contrastantes. Não somente o conjunto de métricas válidas para cada tipo de meso-hábitat diferiu, mas também o escore final e classificação dos mesohábitats avaliados. Isso destaca a importância de se considerar a variabilidade estrutural e biológica dos ambientes aquáticos para a detecçáo de perda da integridade causada por interferências antrópicas.

Palavras-chave: ictiofauna, qualidade do hábitat, conservação, IBI, monitoramento biológico.

\section{Introduction}

The Index of Biotic Integrity (IBI, Karr 1981) has been employed increasingly over the last three decades in the bioassessment of tropical streams; however, as an index originally developed for temperate regions, it is often subject to regional modifications (see review in Jaramillo-Villa and Caramaschi, 2008). Aspects related to the sampling and identification of organisms, as well as operating costs, have limited the use of this index more extensively in tropical biomonitoring protocols (Flotemersch et al., 2006). Nevertheless, IBI assessments based on fish assemblages are preferable, for several reasons, to IBI indexes based on other taxonomic groups, such as macroinvertebrates 
(Roset et al., 2007; Jaramillo-Villa and Caramaschi, 2008). Due to operational constraints and vagility, fish are usually sampled on a reach scale (stretch of 50 to 100 meters long) (Plafkin et al., 1989; Barbour et al., 1999). Consequently, aspects of fish fidelity to habitat features expressed on more inclusive spatial scales, such as micro- and mesohabitat scales, are underestimated. Although individuals of certain taxa (e.g., Astyanax species) can perform short upstream and downstream migrations (Agostinho et al., 2004), others, such as Hypostomus (Ito et al., 2009) and Isbrueckerichthys, show high site fidelity. In particular, this last one can remain in extremely restricted areas, sometimes less than $10 \mathrm{~m}^{2}$ (Gerhard, 1999).

Stream reaches frequently have complex, highly variable longitudinal profiles, primarily related to depth, water velocity, and substrate composition. Three physiognomies are easily identified from their geomorphological and hydrological features within reaches: riffles, runs, and pools. Several studies have highlighted the importance of the mesohabitat scale for understanding the functioning of lotic environments (e.g., Pusey et al., 1998; Kennard et al., 2006; Gosselin et al., 2012; Teresa and Casatti, 2012). The choice of this spatial scale also influences the metrics used to assess the conservation status of an area (Didier and Kestemont, 1996). Studies in tropical and temperate regions generally indicate that riffles exhibit more temporal variation in species composition, whereas pools exhibit greater spatial variation in species composition (Gelwick, 1990) and show higher values of species richness and abundance (Kennard et al., 2006).

Although it is well known that fish respond to different types of mesohabitats (Gelwick, 1990; Bührnheim and Cox-Fernandes, 2003), this information is not directly considered in the biotic indices previously proposed. However, certain metrics usually included in IBI protocols assessed over an entire stream reach may respond in a particular way in each mesohabitat type. For example, the richness of rheophilic species may be a useful metric for distinguishing the conservation status of different riffles but would be uninformative for pools, which are naturally dominated by limnophilic species (Teresa and Casatti, 2012). Moreover, certain metrics can be overestimated or underestimated if the stretch is considered as a whole, as they are dependent on the variety, number and distribution of mesohabitats within the selected stream stretch. In this sense, knowing how the biotic indexes represent the different mesohabitats is of great practical importance.

In this study, we evaluated the ability of the IBI based on the fish fauna to distinguish reference streams from degraded streams through an approach at the mesohabitat scale. As the taxonomic and functional composition of the fish fauna varies with the mesohabitat type (Teresa and Casatti, 2012), it is probable that different metrics are effective in each mesohabitat type. These differences will directly influence the composition of the index and will therefore affect the assessment of the conservation status of a site.

\section{Material and Methods}

\subsection{Study area}

The study area is located in the northwestern portion of the state of São Paulo, Brazil, in the São José dos Dourados basin. The basin drains an area of 614,200 ha, including 25 municipalities with approximately 214,500 inhabitants (Nalon et al., 2008). The geological origin of this basin, with igneous basalt rocks of the Serra Geral formation and surface sedimentary rocks of the Bauru and Cauia groups with inputs from the Botucatu and Pirambóia sand formations present in deep aquifers (IPT, 2000), makes the soil highly susceptible to erosion (Silva et al., 2007). The climate is classified as hot tropical, with maximum mean temperatures ranging from 31 to $32{ }^{\circ} \mathrm{C}$ and minimum mean temperatures from 13 to $14{ }^{\circ} \mathrm{C}$. The average annual rainfall ranges from 1,300 to $1,800 \mathrm{~mm}$ (Nimer, 1989). According to a recent survey (Nalon et al., 2008), only 3.6\% of the area of the São José dos Dourados basin is occupied by natural vegetation. The remainder, including the riparian areas, is occupied primarily by pasture and sugar cane (Silva et al., 2007).

\subsection{Sampling design and fish collection}

Several environmental factors influence the structure of fish assemblages at different spatial scales and can affect the quality of multimetric indices based on information from the ichthyofauna (Tejerina-Garro et al., 2005). To minimize such influences, streams with similar volume and physical habitat structure and situated in the same geographic area with similar types of impacts were selected for study. To find study sites meeting these criteria, a total of eighty streams were visited, from which six were selected (Figure 1, Table 1); three of these were considered reference streams and three degraded 
streams. According to Hughes (1995), a reference scenario should be based on conditions observed in areas affected by as little human interference as possible on regional and site-specific scales. The reference streams for this study were located within the largest forest fragment (seasonal semideciduous forest, $>1,600$ ha in area) in the basin and represent the best-preserved habitat in the region (Figure 1). The degraded streams are located in areas dominated by pasture, have no evidence of chemical pollution, and lack arboreal vegetation in their riparian zone (Figure 1). No representative forest remnants are associated with the deforested streams upstream or downstream from the study sites. According to previous assessments (Casatti et al., 2006, 2009), physical degradation of habitat is the principal threat to the integrity of the fish fauna in the study area, particularly as a result of the removal of riparian vegetation and habitat simplification.

We sampled 96 mesohabitats, 48 of which were in reference streams and 48 in degraded streams. Each habitat unit sampled was five meters in length. We sampled the fish fauna and environmental variables during periods with low precipitation (September to November 2009 and April to July 2010). Each physiographic unit of the stream,
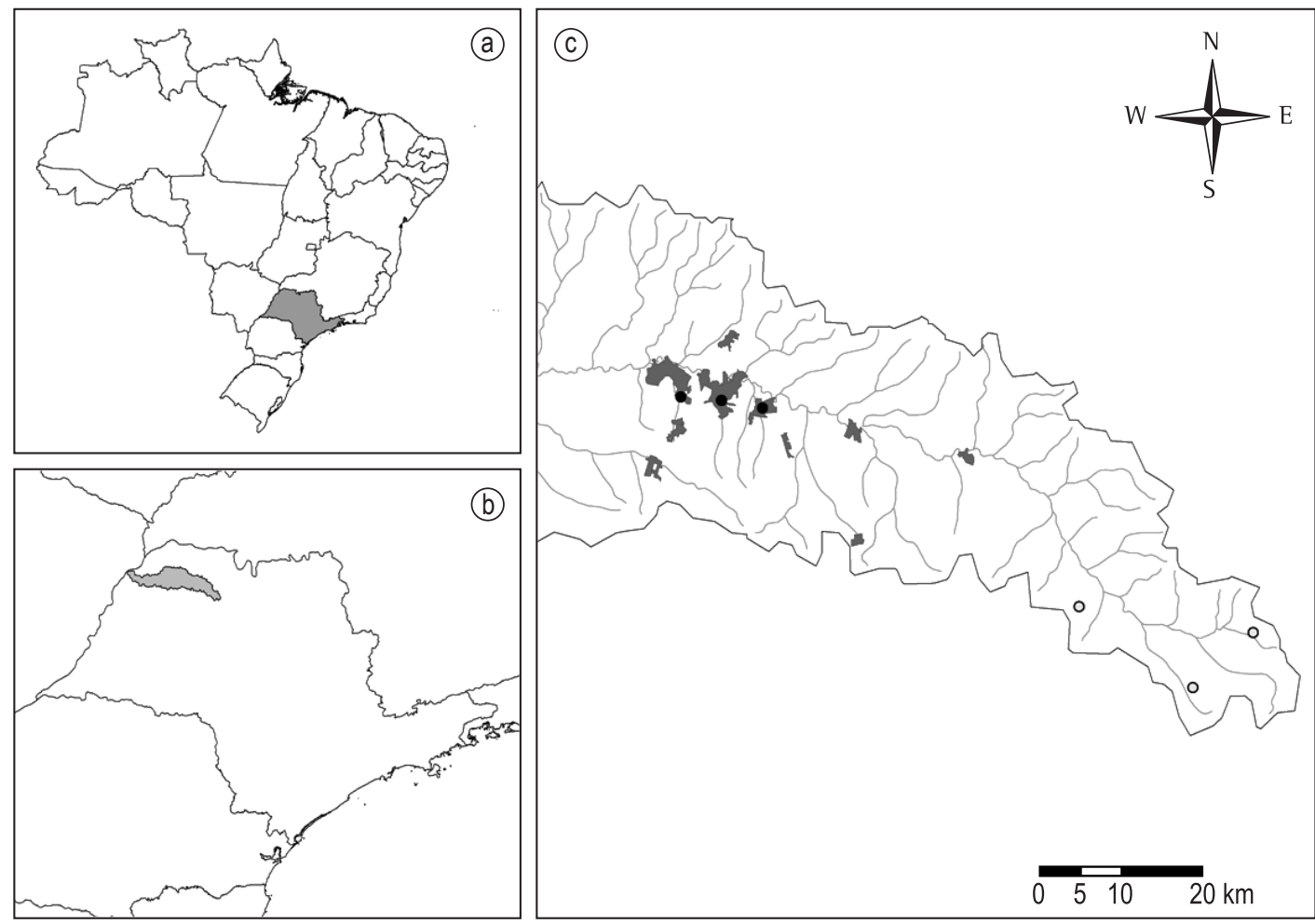

$\begin{array}{lll}5 & 10 & 20 \\ \mathrm{~km}\end{array}$

Figure 1. Location of the study area with the three reference sites (black circles) and three degraded sites (open circles) in the São José dos Dourados basin, northwestern region of the state of São Paulo, Brazil. Large forest fragments ( $>100 \mathrm{ha}$ ) present in the basin are shown (shaded area in the panel c).

Table 1. Location of the selected streams in the São José dos Dourados basin, northwestern region of the state of Sáo Paulo, Brazil.

\begin{tabular}{|c|c|c|c|c|}
\hline Group & Code & Coordinates & Stream name & Municipality \\
\hline \multirow{3}{*}{ 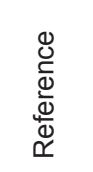 } & $\mathrm{R} 1$ & $20^{\circ} 31^{\prime} 11.22 " \mathrm{~S} 50^{\circ} 10^{\prime} 57.54^{\prime \prime} \mathrm{W}$ & Córrego São Francisco & São João de Iracema \\
\hline & $\mathrm{R} 2$ & $20^{\circ} 30^{\prime} 41.80^{\prime \prime} \mathrm{S} 50^{\circ} 13^{\prime} 45.64^{\prime \prime} \mathrm{W}$ & Córrego Macaubas & São João de Iracema \\
\hline & R3 & $20^{\circ} 30^{\prime} 10.53^{\prime \prime} \mathrm{S} 50^{\circ} 16^{\prime} 44.80^{\prime \prime} \mathrm{W}$ & Córrego Santa Cruz & São João de Iracema \\
\hline \multirow{3}{*}{ 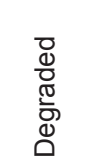 } & D1 & $20^{\circ} 45^{\prime} 49.99^{\prime \prime} \mathrm{S} 49^{\circ} 36^{\prime} 9.10^{\prime \prime} \mathrm{W}$ & Córrego do Tatu & Bálsamo \\
\hline & D2 & $20^{\circ} 50^{\prime} 3.69^{\prime \prime} \mathrm{S} 49^{\circ} 40^{\prime} 8.14^{\prime \prime} \mathrm{W}$ & Córrego Água Limpa & Neves Paulista \\
\hline & D3 & $20^{\circ} 44^{\prime} 8.37^{\prime \prime} \mathrm{S} 49^{\circ} 48^{\prime} 32.67^{\prime \prime} \mathrm{W}$ & Córrego Taperão & Poloni \\
\hline
\end{tabular}


distinguishable according to depth, substrate composition and flow, was considered a mesohabitat and was treated as an independent sample. Habitat units that were shallow, with a rocky or gravelly substrate and a strong to moderate current, were classified as riffles. Units with a greater depth, an unconsolidated (litter) or sandy substrate and a slow stream flow (near zero) were classified as pools. Units with intermediate values of these parameters, i.e., a moderate depth and current and a sandy substrate, were classified as runs. This pattern of physical variation is common in streams in northwestern São Paulo state, a region of gradual slopes with a regular drainage network.

Each mesohabitat was isolated upstream and downstream with block nets before sampling to prevent fish emigration or immigration during electrofishing. The distance among the mesohabitat samples was variable ( -3 to 300 meters). To test the independence of the samples and, thus, to determine whether the distances between samples influenced the biological patterns observed within each stream, the relationship of mesohabitat distance to the fish composition, represented by a similarity matrix based on a Jaccard coefficient, and to the IBI values was tested a priori with a Relate routine (seriation function) for the fish composition and a Mantel test for the IBI values. These analyses showed that the distance between mesohabitats did not influence the fish composition or the IBI values ( $\mathrm{p}>0.07$ ) and, thus, these sampling units can be considered as independent. Fish were collected with electrofishing (stationary generator, AC, $220 \mathrm{~V}, 50-60 \mathrm{~Hz}, 3.4-4.1 \mathrm{~A}, 1000 \mathrm{~W}$, as detailed by Castro et al., 2003) through successive passes along the sample unit. When an electrofishing pass through a habitat unit captured no fish, the sampling of that habitat unit was terminated. The fish caught were fixed in a $10 \%$ formalin solution for 48 hours and then transferred to a $70 \%$ ethanol solution. Voucher specimens of all species were deposited at the fish collection of the Departamento de Zoologia e Botânica da Universidade Estadual Paulista (DZSJRP), São José do Rio Preto, São Paulo, Brazil.

\subsection{Data analysis, metric selection and scoring}

Information on the origin, habitat use, trophic guild, and tolerance of the fish species collected was obtained from published compilations (Bozzetti and Schulz, 2004; Casatti et al., 2009), supplemented by personal observations for species not mentioned in those studies. A qualitative analysis of metrics from the literature (Karr et al., 1986; Miller et al., 1988; Oberdorff and Hughes, 1992; Harris, 1995; Lyons et al., 1995; Roth et al., 2000; Ganasan and Hughes, 1998; Kamdem Toham and Teugels, 1999; McCormick et al., 2001; Ferreira and Casatti 2006; Benejam et al., 2008; Casatti et al., 2009) resulted in the selection of 12 attributes for the local fauna: the percentage of total abundance represented by native species, the percentage of total richness represented by Characiformes and Siluriformes, the percentage of total abundance represented by Characiformes and Siluriformes, the percentage of total richness represented by Siluriformes, the Simpson dominance index, the percentage of total species represented by nektonic species, the percentage of total abundance represented by nektonic abundance, the percentage of total species represented by rheophilic species, the percentage of total abundance represented by rheophilic abundance, the percentage of total species represented by tolerant species, the percentage represented by individuals tolerant to hypoxia, and the percentage of total abundance represented by Poecilia reticulata.

The metrics that differed significantly between the reference and degraded streams ( $t$ test, $\mathrm{p}<0.05$ ) were selected for use in the IBI (Baptista et al., 2007). After this set of metrics was identified, the individual metrics to be used in the IBI were scored as 1,3 , or 5 on the basis of comparisons with the distributions of the metric values at the reference sites. A score of 5 indicates that a sample can be considered equivalent to the reference condition, a score of 3 indicates an intermediate condition, and a score of 1 indicates the greatest deviation from the expected reference condition (Baptista et al., 2007). Box-and-whisker plots of all reference site values obtained for each metric individually were used to define the lower and upper thresholds for this scoring system. For a metric that is expected to have decreasing numbers in response to disturbance, the values above the lower quartile $(25 \%)$ of the reference distribution would score 5 , the values below the lower threshold would score 1 , and intermediate values would score 3 . For a metric expected to have increasing numbers in response to disturbance, the values lower than the upper quartile $(75 \%)$ would score 5 , the values above the upper threshold would score 1, and intermediate values would score 3 (Baptista et al., 2007). The final IBI calculation for each mesohabitat was obtained from the average value of all scores for each group of samples and classified in terms of four 
categories of biotic integrity (good, fair, poor, very poor), following a regional adaptation developed by Casatti et al. (2009) (Table 2). A one-way ANOVA complemented by a post hoc LSD test, both at a significance level of 0.05 , was used to compare IBI values among mesohabitat types.

\section{Results}

Overall, a total of 31 species were caught in the reference and degraded sites (Table 3). Ten of the 12 metrics were significant for runs, six for riffles, and ten for pools (Tables 4 and 5). A comparison of the reference sites with the degraded sites based on the significant metrics showed that the mean values of the IBI for runs and riffles in the degraded sites indicated poor conditions despite great variation in the IBI values, with individual sample units ranging from fair to very poor (Figure 2). The mean values for pools, in contrast, indicated poor conditions (Figure 2). In general, the IBI calculated for pools was significantly lower than that calculated for runs

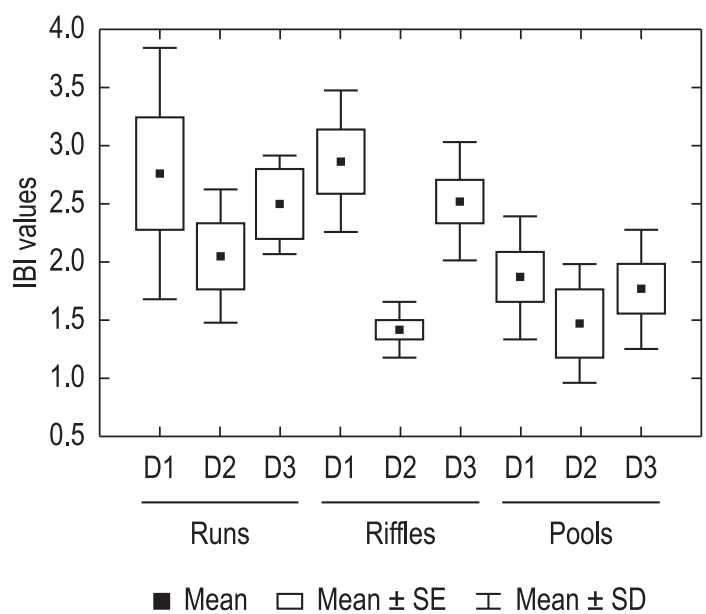

Figure 2. Graphic representations of IBI values calculated for each mesohabitat in degraded streams (SE, standard error; SD, standard deviation). and riffles (one-way ANOVA: $\mathrm{F}=3.35, \mathrm{p}=0.044$; post-hoc LSD, $\mathrm{p}_{\text {runs } \times \text { pools }}=0.02, \mathrm{p}_{\text {riffles } \times \text { pools }}=0.04$, $\left.\mathrm{p}_{\text {runs } \times \text { riffles }}=0.47\right)$.

\section{Discussion}

Our results show that the calculation of the IBI according to mesohabitat may be a useful strategy for assessing the integrity of streams. Certain metrics successfully distinguished degraded from reference conditions regardless of the mesohabitat type. However, other metrics showed a differential sensitivity to degradation depending on the mesohabitat type considered. Furthermore, the IBI values obtained in this study show that mesohabitat types differ in their conservation status, information that can have practical implications. In a management context, calculating the IBI according to mesohabitat can help to identify stream sites that require relatively more intervention than others in terms of possible aquatic habitat restoration. The mesohabitat approach can also be a strategy of interest for reducing sampling costs because mesohabitat differences are continually cited as an impediment to the use of fish as indicators of river and stream quality (Jaramillo-Villa and Caramaschi, 2008). In addition, the mesohabitat approach can result in the handling of fewer individuals and thus minimize the impact of sampling on fish welfare.

The degraded runs and pools contained a greater number of species than the reference runs and pools (see Table 3). This finding was not consistent with the customary prediction because the number of species normally tends to decrease with increasing degradation (Karr, 1981; Karr et al., 1986; Casatti et al., 2009), with certain exceptions (e.g., Bojsen and Barriga, 2002; Lorion and Kennedy, 2009; Teresa and Casatti, 2010). Callichthys callichthys, Corydoras aeneus, Geophagus brasiliensis, Serrapinnus notomelas, and Synbranchus marmoratus, species frequently found in degraded sites (Graham

Table 2. Detailed descriptions of stream biological integrity associated with each of the IBI categories (Casatti et al., 2009).

\begin{tabular}{|c|c|c|}
\hline Categories & Values & Descriptions \\
\hline Good & $4.0-5.0$ & $\begin{array}{l}\text { Comparable to reference streams and considered minimally impacted. On average, biological } \\
\text { metrics fall within the upper } 75 \% \text { of the reference conditions. }\end{array}$ \\
\hline Fair & 3.0-3.9 & $\begin{array}{l}\text { Comparable to reference streams, however with some aspects of biological integrity compromised. } \\
\text { On average, biological metrics are within the } 75 \text { and } 50 \% \text { of the reference conditions. }\end{array}$ \\
\hline Poor & $2.0-2.9$ & $\begin{array}{l}\text { Significant deviation of the reference condition, with many aspects of biological integrity not } \\
\text { resembling the quality of minimally impacted streams. On average, biological metrics are within } \\
50 \text { and } 25 \% \text { of the reference conditions. }\end{array}$ \\
\hline Very poor & $0-1.9$ & $\begin{array}{l}\text { Strong deviation of the reference condition, with many aspects of biological integrity endangered, } \\
\text { indicating severe degradation. The majority of biological metrics fall below } 25 \% \text { of the reference } \\
\text { conditions. }\end{array}$ \\
\hline
\end{tabular}


Table 3. List of collected species, presenting their abundance in the reference (R) and degraded streams (D), total richness, and average richness by mesohabitat. Classification follows Buckup et al. (2007).

\begin{tabular}{|c|c|c|c|c|c|c|}
\hline Orders, families and species & R1 & R2 & R3 & D1 & D2 & D3 \\
\hline \multicolumn{7}{|l|}{ Order Characiformes } \\
\hline \multicolumn{7}{|l|}{ Family Parodontidae } \\
\hline Parodon nasus Kner, 1859 & 1 & 1 & - & 2 & 1 & 1 \\
\hline \multicolumn{7}{|l|}{ Family Curimatidae } \\
\hline Cyphocharax modestus (Fernández-Yépez, 1948) & - & - & - & - & 2 & - \\
\hline Steindachnerina insculpta (Fernández-Yépez, 1948) & 1 & 1 & - & 2 & - & 5 \\
\hline \multicolumn{7}{|l|}{ Family Anostomidae } \\
\hline Leporinus friderici (Bloch, 1794) & 2 & 4 & - & - & - & - \\
\hline \multicolumn{7}{|l|}{ Family Crenuchidae } \\
\hline Characidium gomesi Travassos, 1956 & - & - & - & 21 & - & 9 \\
\hline Characidium zebra Eigenmann, 1909 & 12 & 51 & 76 & 1 & - & 9 \\
\hline \multicolumn{7}{|l|}{ Family Characidae } \\
\hline Astyanax altiparanae Garutti and Britski, 2000 & 58 & 25 & 22 & 33 & 3 & 27 \\
\hline Astyanax fasciatus (Cuvier, 1819) & 5 & 34 & 138 & 230 & - & 63 \\
\hline Bryconamericus stramineus Eigenmann, 1908 & - & - & - & 13 & - & 67 \\
\hline Hemigrammus marginatus Ellis, 1911 & 2 & - & - & - & - & 1 \\
\hline Knodus moenkhausii (Eigenmann and Kennedy, 1903) & 8 & 30 & 10 & - & - & - \\
\hline Oligosarcus pintoi Campos, 1945 & - & - & 2 & 6 & 8 & 3 \\
\hline Piabina argentea Reinhardt, 1867 & 6 & 33 & 40 & 33 & 35 & 79 \\
\hline Planaltina britskii Menezes, Weitzman and Burns, 2003 & 1 & 1 & - & - & - & - \\
\hline Serrapinnus notomelas (Eigenmann, 1915) & & - & - & 24 & 2 & 1 \\
\hline \multicolumn{7}{|l|}{ Family Erythrinide } \\
\hline Hoplias malabaricus (Bloch, 1794) & - & - & - & 8 & 5 & 3 \\
\hline \multicolumn{7}{|l|}{ Order Siluriformes } \\
\hline \multicolumn{7}{|l|}{ Family Callichthyidae } \\
\hline Aspidoras fuscoguttatus Nijssen and Isbrücker, 1976 & - & 9 & 23 & 6 & 18 & - \\
\hline Callichthys callichthys (Linnaeus, 1758) & - & - & - & 3 & 2 & - \\
\hline Corydoras aeneus (Gill, 1858) & - & 1 & - & 44 & 25 & 33 \\
\hline \multicolumn{7}{|l|}{ Family Loricariidae } \\
\hline Hisonotus francirochai (Ihering, 1928) & - & - & - & 52 & 12 & 6 \\
\hline Hypostomus ancistroides (Ihering, 1911) & 7 & 17 & 36 & 108 & 92 & 123 \\
\hline Hypostomus nigromaculatus (Schubart, 1964) & 32 & 42 & 86 & 30 & 1 & 2 \\
\hline Hypostomus sp. 1 & 1 & - & - & - & - & - \\
\hline Hypostomus sp. 2 & - & - & - & 1 & - & - \\
\hline \multicolumn{7}{|l|}{ Family Pseudopimelodidae } \\
\hline Pseudopimelodus pulcher (Boulenger, 1887) & 10 & 35 & - & - & - & - \\
\hline \multicolumn{7}{|l|}{ Family Heptapteridae } \\
\hline Cetopsorhamdia iheringi Schubart and Gomes, 1959 & 1 & 9 & 25 & - & - & - \\
\hline Imparfinis mirini Haseman, 1911 & 2 & 2 & - & 4 & - & 3 \\
\hline Imparfinis schubarti (Gomes, 1956) & - & 13 & - & 34 & 8 & 13 \\
\hline Pimellodela avanhandavae Eigenmann, 1917 & 9 & 6 & - & 5 & - & 2 \\
\hline Rhamdia quelen (Quoy and Gaimard, 1824) & 1 & 10 & 14 & 19 & 8 & 1 \\
\hline \multicolumn{7}{|l|}{ Family Pimelodidae } \\
\hline Pimelodus maculatus LaCepède, 1803 & 1 & - & - & - & - & - \\
\hline \multicolumn{7}{|l|}{ Family Auchenipteridae } \\
\hline Tatia neivai (Ihering, 1930) & 3 & - & - & - & - & - \\
\hline \multicolumn{7}{|l|}{ Order Gymnotiformes } \\
\hline \multicolumn{7}{|l|}{ Family Gymnotidae } \\
\hline Gymnotus sylvius Albert and Fernandes-Matioli, 1999 & 2 & 4 & - & 2 & 96 & 87 \\
\hline \multicolumn{7}{|l|}{ Family Sternopygidae } \\
\hline Eigenmannia trilineata López and Castello, 1966 & 3 & - & - & - & - & - \\
\hline Eigenmannia virescens (Valenciennes, 1836) & 7 & 1 & - & - & - & - \\
\hline Sternopygus macrurus (Bloch and Schneider, 1801) & 3 & - & - & - & - & - \\
\hline Order Cyprinodontiformes & & & & & & \\
\hline
\end{tabular}


Table 3. Continued...

\begin{tabular}{lcccccc}
\hline \multicolumn{1}{c}{ Orders, families and species } & R1 & R2 & R3 & D1 & D2 & D3 \\
\hline Family Poeciliidae & & & & & & \\
$\quad$ Phalloceros harpagos Lucinda, 2008 & - & - & - & 2 & 16 & 5 \\
$\quad$ Poecilia reticulata Peters, 1859 & - & 5 & - & 67 & 33 & 48 \\
Order Synbranchiformes & & & & & & \\
Family Synbranchidae & & & & & & \\
$\quad$ Synbranchus marmoratus Bloch, 1785 & - & - & - & 1 & 1 & 2 \\
Order Perciformes & & & & & & \\
Family Cichlidae & & & & & & \\
$\quad$ Cichlasoma paranaense Kullander, 1983 & 1 & - & - & - & - & - \\
$\quad$ Crenicichla britskii Kullander, 1982 & 1 & 2 & - & 5 & 27 & 10 \\
$\quad$ Geophagus brasiliensis (Quoy and Gaimard, 1824) & - & - & - & 35 & - & 31 \\
$\quad$ Oreochromis niloticus (Linnaeus, 1758) & - & - & - & 1 & - & 1 \\
Species richness & 26 & 23 & 11 & 29 & 20 & 27 \\
Average richness at runs & 6 & 7 & 6 & 11 & 9 & 6 \\
Average richness at riffles & 5 & 7 & 7 & 9 & 7 & 8 \\
Average richness at pools & 5 & 8 & 6 & 15 & 8 & 11 \\
\hline
\end{tabular}

Table 4. Expected response of each metric value considering the increasing of degradation. Results of $t$-test for metric discrimination between reference and degraded runs, riffles, and pools. Bold values indicate valid metrics $(\mathrm{p}<0.05)$.

\begin{tabular}{lcrrr}
\hline \multicolumn{1}{c}{ Metrics } & Expected response & Runs & \multicolumn{1}{c}{ Riffles } & Pools \\
\hline Percent of native abundance & decrease & $\mathbf{2 . 7 6 8 8}$ & -0.7993 & 4.3028 \\
Percent of Characiformes and Siluriformes richness & decrease & $\mathbf{2 . 5 8 9 9}$ & $\mathbf{4 . 9 6 2 4}$ & 5.2367 \\
Percent of Characiformes and Siluriformes abundance & decrease & $\mathbf{3 . 9 8 6 7}$ & $\mathbf{4 . 0 3 6 7}$ & $\mathbf{4 . 7 7 2 6}$ \\
Percent of Siluriformes richness & decrease & 0.5856 & 1.4955 & 4.1657 \\
Simpson dominance & decrease & -0.1108 & 0.3947 & 1.5268 \\
Percent of nektonic species & decrease & $\mathbf{2 . 7 1 5 4}$ & 0.8212 & 2.7630 \\
Percent of nektonic abundance & decrease & $\mathbf{2 . 4 1 2 6}$ & -0.0371 & 1.7477 \\
Percent of rheophilic species & decrease & $\mathbf{3 . 0 8 7 8}$ & $\mathbf{6 . 9 8 6 9}$ & $\mathbf{4 . 8 9 9 5}$ \\
Percent of rheophilic abundance & decrease & $\mathbf{3 . 9 0 9 3}$ & $\mathbf{1 1 . 8 3 1 9}$ & $\mathbf{4 . 0 0 7 4}$ \\
Percent of tolerant species & increase & $-\mathbf{2 . 4 9 9 5}$ & $-\mathbf{3 . 4 2 3 1}$ & $-\mathbf{3 . 8 2 0 1}$ \\
Percent of tolerant individuals to hypoxia & increase & $-\mathbf{3 . 3 2 2 2}$ & $-\mathbf{7 . 7 6 1 5}$ & $-\mathbf{4 . 4 6 3 9}$ \\
Percent of abundance of Poecilia reticulata & increase & $\mathbf{- 2 . 7 6 8 8}$ & 0.7993 & $-\mathbf{4 . 2 3 9 1}$ \\
\hline
\end{tabular}

and Baird, 1984; Mol, 1994; Araújo et al., 2009), occurred only in the degraded runs and pools. In contrast, Cetopsorhamdia iheringi, Pseudopimelodus pulcher, and Tatia neivai were most frequent in the reference sites. These findings support the view that richness metrics, although useful in certain cases, do not reveal functional aspects of fish assemblages and must be evaluated with caution in monitoring assessments (Fausch et al., 1990).

The metrics that distinguished the reference sites from the degraded sites varied according to the mesohabitat type considered. For example, the metrics based on the nektonic species percentage, nektonic species abundance percentage, Siluriformes species percentage, and Poecilia reticulata percentage distinguished the degraded from the reference sites in only one or two of the sampled mesohabitats (see Table 4). This result indicates that the metrics are context dependent, i.e., their ability to distinguish reference sites from degraded sites varies across mesohabitats. Thus, the approach traditionally used to assess biotic integrity can result in the overestimation or underestimation of environmental quality, as streams may include qualitative and quantitative mesohabitat differences.

Although all degraded mesohabitats showed meaningful deviations from the forested sites chosen to represent the reference condition, the riffles and runs were found to have better conditions than the pools, which were the mesohabitats in the worst state of degradation. In riffles and runs, hydrological conditions may be the primary factors restricting fish occurrence (Lamouroux and Cattanéo, 2006). Although certain aspects of the habitat were impaired in the degraded riffles (e.g., deforested banks, moderate siltation), the maintenance of 
Table 5. Scoring criteria used for IBI metrics adapted for runs, riffles, and pools, where $\mathrm{x}$ is the observed value for each metric.

\begin{tabular}{|c|c|c|c|}
\hline \multirow{2}{*}{ Metrics } & \multicolumn{3}{|c|}{ Scoring criteria } \\
\hline & 5 & 3 & 1 \\
\hline \multicolumn{4}{|l|}{ Runs: } \\
\hline Percent of native abundance & $x=100$ & - & $x<100$ \\
\hline Percent of Characiformes and Siluriformes richness & $x \geq 88$ & $78 \leq x<88$ & $x<78$ \\
\hline Percent of Characiformes and Siluriformes abundance & $x \geq 96$ & $90 \leq x<96$ & $x<90$ \\
\hline Percent of nektonic species & $x \geq 29$ & $23 \leq x<29$ & $x<23$ \\
\hline Percent of nektonic abundance & $x \geq 29$ & $19 \leq x<29$ & $x<19$ \\
\hline Percent of rheophilic species & $x \geq 16$ & $0<x<16$ & $x=0$ \\
\hline Percent of rheophilic abundance & $x \geq 12$ & $0<x<12$ & $x=0$ \\
\hline Percent of tolerant species & $x \leq 45$ & $67 \geq x>45$ & $x>67$ \\
\hline Percent of tolerant individuals to hypoxia & $x \leq 52$ & $64 \geq x>52$ & $x>64$ \\
\hline Percent of abundance of Poecilia reticulate & $x=0$ & - & $x<0$ \\
\hline \multicolumn{4}{|l|}{ Riffles: } \\
\hline Percent of Characiformes and Siluriformes richness & $x \geq 88$ & $82 \leq x<88$ & $x<82$ \\
\hline Percent of Characiformes and Siluriformes abundance & $x \geq 96$ & $90 \leq x<96$ & $x<90$ \\
\hline Percent of rheophilic species & $x \geq 43$ & $33<x<43$ & $x<33$ \\
\hline Percent of rheophilic abundance & $x \geq 62$ & $56<x<62$ & $x<56$ \\
\hline Percent of tolerant species & $x \leq 45$ & $67 \geq x>45$ & $x>67$ \\
\hline Percent of tolerant individuals to hypoxia & $x \leq 52$ & $64 \geq x>52$ & $x>64$ \\
\hline \multicolumn{4}{|l|}{ Pools: } \\
\hline Percent of native abundance & $x=100$ & - & $x<100$ \\
\hline Percent of Characiformes and Siluriformes richness & $x \geq 90$ & $75 \leq x<90$ & $x<75$ \\
\hline Percent of Characiformes and Siluriformes abundance & $x \geq 95$ & $87 \leq x<95$ & $x<87$ \\
\hline Percent of Siluriformes richness & $x \geq 50$ & $33 \leq x<50$ & $x<33$ \\
\hline Percent of nektonic species & $x \geq 33$ & $25 \leq x<33$ & $x<25$ \\
\hline Percent of rheophilic species & $x \geq 13$ & $0<x<13$ & $x=0$ \\
\hline Percent of rheophilic abundance & $x \geq 5$ & $0<x<5$ & $x=0$ \\
\hline Percent of tolerant species & $x=0$ & $20 \geq x>0$ & $x>20$ \\
\hline Percent of tolerant individuals to hypoxia & $x=0$ & $10 \geq x>0$ & $x>10$ \\
\hline Percent of abundance of Poecilia reticulate & $x=0$ & - & $x>0$ \\
\hline
\end{tabular}

hydrological characteristics (shallow and fast waters) may have been sufficient to guarantee a relatively high similarity between the fish fauna of the degraded riffles and that of the forested riffles. Nevertheless, pools are more susceptible to the deposition of small particles and are more vulnerable to siltation. The strong deviation from the reference condition found for pools indirectly reflects the effects of siltation, which may decrease the survival of fry or prevent the reproduction of lithophilous species (Berkman and Rabeni, 1987).

None of the metrics that assessed the composition of the fish fauna in terms of native and non-native species was able to discriminate the reference riffles from the degraded riffles. This finding indicates the influence of a context-dependent situation. The non-native species found in this study have relatively sedentary habits (as in the case of Oreochromis niloticus and Poecilia reticulata) and are naturally uncommon in riffles. Note that the fish fauna evaluated here is exposed to impacts of various forms but still does not suffer from exhaustive pressure from the non-native fauna, as in many tropical systems, where a large portion of the fish fauna is represented by non-native species (Hughes and Oberdorff, 1999).

The species richness and abundance metrics for Characiformes and Siluriformes distinguished the reference mesohabitats from the degraded mesohabitats in all conditions. The predominance of these two orders in protected rivers and streams in the Neotropical region follows well-known patterns (Castro et al., 2003, 2004), but more tolerant species and/or non-native species belonging to the orders Perciformes and Cyprinodontiformes can proliferate under degraded conditions (Pinto et al., 2006; Casatti et al., 2009), modifying the expected balance between the two groups of orders cited, as found in this study. 
The nektonic guild discriminated the reference runs and pools from the degraded mesohabitats and represented context-dependent metrics. This metric was originally proposed as the number of species in the water column, and an increase in its value may be an indicator of conservation (Karr, 1981). After studying streams in southern Brazil, Bozzetti and Schulz (2004) considered this guild to represent an indicator of degradation because a loss of habitat complexity caused by the input of fine sediment would make the environment less favorable to benthic and more favorable to nektonic individuals. In extremely silted streams, even nektonic fish are unable to establish themselves due to the reduction of the habitat volume, which affects their swimming performance and displacement in the water column (Casatti et al., 2009). The results of the current study support this observation because the runs and pools in the forested sites were able to accommodate a greater number of nektonic species. Although nektonic richness was higher in the reference pools, the abundance was similar, indicating a greater dominance by nektonic species in the degraded pools. This finding is consistent with the observed structural simplification in the degraded pools.

According to Joy and Death (2004), variation in catchability can be a potential source of error in the metrics of abundance used to assess biotic integrity. Previous studies conducted to refine the IBI metrics for fish in streams show great variation in sampling effort, as determined by the width and depth of the stream reaches. Generally, sampling protocols should be able to obtain a representative sample of the habitats present at a site (Karr, 1981), ranging from two-pass electrofishing for 75 meters (Roth et al., 1999) to one pass for 93 meters (Schleiger, 2000) and three passes for 100-150 meters (Bozzetti and Schulz, 2004). Although electrofishing is known to be effective for collecting fish in streams of low order, several factors can affect its efficiency, including conductivity, turbidity, seasonal fluctuations, flow, and especially channel depth and width (Zalewski and Cowx, 1990). Given the sampling limitations found in bioassessment protocols, the mesohabitat approach may be a promising strategy because it minimizes the number of individuals that escape from the sampled site and yields a more accurate snapshot of the fish fauna.

In conclusion, the assessment of biotic integrity differed among the mesohabitat types, particularly in terms of the set of valid metrics. This study emphasizes the importance of considering the structural and biological variability of aquatic environments to capture the significance of a loss of integrity due to human influence. These considerations are more important than the actual evaluation of the integrity of each sample unit. Several previous studies indicate the advantages of using fish in the evaluation of streams (e.g., Karr, 1981; Roset et al., 2007; Jaramillo-Villa and Caramaschi, 2008), but it is still necessary to expand existing knowledge about the possible biological indicators in tropical streams, particularly in terms of the ecological processes in these ecosystems (Jaramillo-Villa and Caramaschi, 2008) and the specific responses of the organisms along the gradient of degradation at different scales.

\section{Acknowledgements}

We thank the Laboratório de Ictiologia colleagues for their help during field work and Departamento de Zoologia e Botânica IBILCEUNESP for facilities; IBAMA for collecting license; landowners for permission to conduct research on their properties; Bernard De Mérona, Fernando M. Pelicice, and anonymous reviewers for comments on this and earlier versions of the manuscript. This study was made possible by funding from FAPESP in the BIOTA/FAPESP Program (www.biota.org/ br). LC received grant from CNPq (141028/20076) and FAPESP (10/12141-0) and FBT received grant from FAPESP (08/03583-9).

\section{References}

AGOSTINHO, AA., GOMES, LC., VERÍSSIMO, S. and OKADA, EK. 2004. Flood regime, dam regulation and fish in the Upper Paraná River: effects on assemblage attributes, reproduction and recruitment. Reviews in Fish Biology and Fisheries, vol. 14, no. 1, p. 11-19. http://dx.doi.org/10.1007/ s11160-004-3551-y

ARAÚJO, FG., PINTO, BCT. and TEIXEIRA, TP. 2009. Longitudinal patterns of fish assemblages in a large tropical river in southeastern Brazil: evaluating environmental influences and some concepts in river ecology. Hydrobiologia, vol. 618, no. 1, p. 89-107. http://dx.doi.org/10.1007/s10750-008-9551-5

BAPTISTA, DF., BUSS, D., EGLER, M., GIOVANELLI, A., SILVEIRA, MP. and NESSIMIAN, JL. 2007. A multimetric index based on benthic macroinvertebrates for evaluation of Atlantic Forest streams at Rio de Janeiro State, Brazil. Hydrobiologia, vol. 575, no. 1, p. 83-94. http://dx.doi.org/10.1007/ s10750-006-0286-x

BARBOUR, MT., GERRITSEN, J., SNYDER, BD. and STRIBLING, JB. 1999. Rapid bioassessment protocols 
for use in streams and wadeable rivers: periphyton, benthic macroinvertebrates and fish. 2nd ed. Washington: U. S. Environmental Protection Agency, Office of Water. EPA 841-B-99-002. Available from: <http://water.epa.gov/scitech/monitoring/rsl/ bioassessment/index.cfm $>$.

BENEJAM, L., APARICIO, E., VARGAS, MJ., VILA-GISPERT, A. and GARCÍA-BERTHOU, E. 2008. Assessing fish metrics and biotic indices in a Mediterranean streams: effects of uncertain native status of fish. Hydrobiologia, vol. 603, no. 1, p. 197-210. http://dx.doi.org/10.1007/s10750007-9272-1

BERKMAN, HE. and RABENI, CF. 1987. Effect of siltation on stream fish communities. Environmental Biology of Fishes, vol. 18, no. 4, p. 285-294. http:// dx.doi.org/10.1007/BF00004881

BOJSEN, BH. and BARRIGA, R. 2002. Effects of deforestation on fish community structure in Ecuadorian Amazon streams. Freshwater Biology, vol. 47, no. 11, p. 2246-2260. http://dx.doi. org/10.1046/j.1365-2427.2002.00956.x

BOZZETTI, M. and SCHULZ, UH. 2004. An index of biotic integrity based on fish assemblages for subtropical streams in southern Brazil. Hydrobiologia, vol. 529, no. 1-3, p. 133-144. http://dx.doi. org/10.1007/s10750-004-5738-6

BUCKUP, PA., MENEZES, NA. and GHAZZI, MS. 2007. Catálogo das espécies de peixes de água doce do Brasil. Rio de Janeiro: Museu Nacional e Universidade Federal do Rio de Janeiro. 195 p.

BÜHRNHEIM, CM. and COX FERNANDES, C. 2003. Structure of fish assemblages in Amazonian Rain-Forest streams: effects of habitats and locality. Copeia, vol. 2003, p. 255-262. http://dx.doi. org/10.1643/0045-8511(2003)003[0255:SOFAIA 12.0. $\mathrm{CO} ; 2$

CASATTI, L., LANGEANI, F., SILVA, AM. and CASTRO, RMC. 2006. Stream fishes, water and habitat quality in a pasture dominated basin, southeastern Brazil. Brazilian Journal of Biology, vol. 66, no. 2b, p. 681-696. http://dx.doi. org/10.1590/S1519-69842006000400012

CASATTI, L., FERREIRA, CP. and CARVALHO, FR. 2009. A fish-based biotic integrity index for assessment of lowland streams in southeastern Brazil. Hydrobiologia, vol. 623, no. 1, p. 173-189. http:// dx.doi.org/10.1007/s10750-008-9656-x

CASTRO, RMC., CASATTI, L., SANTOS, HF., FERREIRA, KM., RIBEIRO, AC., BENINE, RC., DARDIS, GZP., MELO, ALA., STOPIGLIA, R., ABREU, TX., BOCKMANN, FA., CARVALHO, M., GIBRAN, FZ. and LIMA, FCT. 2003. Estrutura e composiçáo da ictiofauna de riachos do Rio Paranapanema, sudeste e sul do Brasil. Biota Neotropica, vol. 3, no. 1, p. 1-31. Available from: <http://www.biotaneotropica.org.br/v3n1/pt/abstr act?article+BN01703012003>.

CASTRO, RMC., CASATTI, L., SANTOS, HF., MELO, ALA., MARTINS, LSF., FERREIRA, KM., GIBRAN, FZ., BENINE, RC., CARVALHO, M., RIBEIRO, AC., ABREU, TX., BOCKMANN, FA., PELIÇÃO, GZ., STOPIGLIA, R. and LANGEANI, F. 2004. Estrutura e composição da ictiofauna de riachos da bacia do Rio Grande no Estado de São Paulo, sudeste do Brasil. Biota Neotropica, vol. 4, no. 1, p. 1-39. Available from <http://www.biotaneotropica. org.br/v4n1/pt/abstract?article+BN01704012004>

DIDIER, J. and KESTEMONT, P. 1996. Relationships between mesohabitats, ichthyological communities and IBI metrics adapted to a European river basin (The Meuse, Belgium). Hydrobiologia, vol. 341, no. 2, p. 133-144. http://dx.doi.org/10.1007/BF00018117

FAUSCH, KD., LYONS, J., KARR, JR. and ANGERMEIER, PL. 1990. Fish communities as indicator of environmental degradation. American Fisheries Society Symposium, vol. 8, p. 123-144.

FERREIRA, CP. and CASATTI, L. 2006. Integridade biótica de um córrego na bacia do Alto Rio Paraná avaliada por meio da comunidade de peixes. Biota Neotropica, vol. 6, no. 3, p. 1-25. Available from: <http://www.biotaneotropica.org.br/v6n3/pt/abstr act?article+bn00306032006>

FLOTEMERSCH, JE., STRIBLING, JB. and PAUL, MJ. 2006. Concepts and approaches for the bioassessment of non-wadeable streams and rivers. Cincinnati: US Environmental Protection Agency. EPA 600-R06-127.

GANASAN, V. and HUGHES, RM. 1998. Application of an index of biological integrity (IBI) to fish assemblages of the rivers Khan and Kshipra (Madhya Pradesh), India. Freshwater Biology, vol. 40, no. 2, p. 367-383. http://dx.doi.org/10.1046/j.13652427.1998.00347.x

GELWICK, FP. 1990. Longitudinal and temporal comparisons of riffle and pool fish assemblage in a northeastern Oklahoma Ozark stream. Copeia, vol. 1990, no. 4, p. 1072-1082. Available from <http://www.jstor.org/stable/1446491>

GERHARD, P. 1999. Ecologia de populaçóes e comportamento de quatro espécies de bagres Heptapterinae (Teleostei: Siluriformes) em riachos do Alto Vale do rio Ribeira (Iporanga, São Paulo). São Paulo: Universidade de São Paulo. 129 p. Unpublished Dissertation.

GOSSELIN, MP., MADDOCK, I. and PETTS, G. 2012. Mesohabitat use by brown trout (Salmo trutta) in a small groundwater-dominated stream. River Research and Applications, vol. 28, no. 3, p. 390-401. http://dx.doi.org/10.1002/rra.1464

GRAHAM, JB. and BAIRD, TA. 1984. The transition to air breathing in fishes: III. Effects of body size and aquatic hypoxia on the aerial gas exchange of 
the swamp eel Synbranchus marmoratus. Journal of Experimental Biology, vol. 108, p. 357-375. Available from: <http://jeb.biologists.org/content/108/1/357. short $>$.

HARRIS, JH. 1995. The use of fish in ecological assessments. Australian Journal of Ecology, vol. 20, no. 1, p. 65-80. http://dx.doi. org/10.1111/j.1442-9993.1995.tb00523.x

HUGHES, RM. 1995. Defining acceptable biological status by comparing with reference conditions. In DAVIS, WS. and SIMON, TP. (Eds.). Biological assessment and criteria: tools for water resource planning and decision making. Boca Raton: CRC Press Inc. 432 p.

HUGHES, RM. and OBERDORFF, T. 1999. Application of IBI concepts and metrics to waters outside the United States and Canada. In SIMON, TP. (Ed.). Assessing the sustainability and biological integrity of water resources using fish communities. Boca Raton: CRC Press Inc. 672 p.

Instituto de Pesquisas Tecnológicas do Estado de São Paulo - IPT. 2000. Diagnóstico da situação atual dos recursos hidricos e estabelecimento de diretrizes técnicas para a elaboração do Plano da Bacia Hidrográfica do São José dos Dourados - minuta. São Paulo: Comitê da Bacia Hidrográfica do São José dos Dourados, Fundo Estadual de Recursos Hídricos.

ITO, KF., RENESTO, E. and ZAWADZKI, CH. 2009. Biochemical comparison of two Hypostomus populations (Siluriformes, Loricariidae) from the Atlântico stream of the upper Paraná River basin, Brazil. Genetics and Molecular Biology, vol. 32, no. 1, p. 51-57. Available from: <http://www.scielo.br/pdf/ gmb/v32n1/v32n1a08.pdf>.

JARAMILLO-VILLA, U. and CARAMASCHI, E. 2008. Índices de integridade biótica usando peixes de água doce: uso nas regióes tropical e subtropical. Oecologia Brasiliensis, vol. 12, no. 3, p. 442-462. Available from: <http:/www.oecologiaaustralis.org/ojs/index.php/ oa/article/viewArticle/116>.

JOY, MK. and DEATH, RG. 2004. Application of the index of biotic integrity methodology to New Zealand freshwater fish communities. Environmental Management, vol. 34, no. 3, p. 415-428. http:// dx.doi.org/10.1007/s00267-004-0083-0

KAMDEM TOHAM, A. and TEUGELS, GG. 1999. First data of an Index if Biotic Integrity (IBI) based on fish assemblage for the assessment of the impact of deforestation in a tropical West African river system. Hydrobiologia, vol. 397, p. 29-38. http://dx.doi. org/10.1023/A:1003605801875

KARR, JR. 1981. Assessment of biotic integrity using fish communities. Fisheries, vol. 6, no. 6, p. 21-27. http://dx.doi.org/10.1577/15488446(1981)006<0021:AOBIUF>2.0.CO;2
KARR, JR., FAUSCH, KD., ANGERMEIER, PL., YANT, PR. and SCHLOSSER, IJ. 1986. Assessing biological integrity in running waters, a method and its rationale. III. Urbana: Natural History Survey. Special Publication 5.

KENNARD, MJ., PUSEY, BJ., HARCH, BD., DORE, E. and ARTHINGTON, AH. 2006. Estimating local stream fish assemblage attributes: sampling effort and efficiency at two spatial scales. Marine and Freshwater Research, vol. 57, no. 6, p. 635-653. http://dx.doi. org/10.1071/MF06062

LAMOUROUX, N. and CATTANÉO, F. 2006. Fish assemblages and stream hydraulics: consistent relations across spatial scales and regions. River Research and Applications, vol. 22, no. 7, p. 727-737. http://dx.doi.org/10.1002/rra.931

LORION, CM. and KENNEDY, BP. 2009. Riparian forest buffers mitigate the effects of deforestation on fish assemblages in tropical headwater streams. Ecological Applications, vol. 19, no. 2, p. 468-479. http://dx.doi.org/10.1890/08-0050.1

LYONS, J., NAVARRO-PÉREZ, S., COCHRAN, PA., SANTANA, E. and GUZMÁN-ARROYO, M. 1995. Index of biotic integrity based on fish assemblages for the conservation of streams and rivers in West-Central Mexico. Conservation Biology, vol. 9, no. 3, p. 569-584. http://dx.doi.org/10.1046/j.15231739.1995.09030569.x

McCORMICK, FH., HUGHES, RM., KAUFMANN, PR., PECK, DV., STODDARD, JL. and HERLIHY, AT. 2001. Development of an index of biotic integrity for the Mid-Atlantic Highlands Region. Transactions of American Fisheries Society, vol. 130, no. 5, p. 857-877. http://dx.doi.org/10.1577/15488659(2001)130<0857:DOAIOB > 2.0.CO;2

MILLER, DL., LEONARD, PM., HUGHES, RM., KARR, JR., MOYLE, PB., SCHRADER, LH., THOMPSON, BA., DANIELS, RA., FAUSCH, KD., FITZHUGH, GA., GAMMON, JR., HALLIWELL, DB., ANGERMEIER, PL. and ORTH, DJ. 1988. Regional applications of an index of biotic integrity for use in water resource management. Fisheries, vol. 13, no. 5, p. 12-20. http:// dx.doi.org/10.1577/1548-8446(1988)013<0012:RA $\mathrm{OAIO}>2.0 . \mathrm{CO} ; 2$

MOL, JH. 1994. Effects of salinity on distribution, growth and survival of three neotropical armoured catfishes (Siluriformes - Callichthyidae). Journal of Fish Biology, vol. 45, no. 5, p. 763-776. http://dx.doi. org/10.1111/j.1095-8649.1994.tb00942.x

NALON, MA., MATTO, ISA. and FRANCO, GADC. 2008. Meio físico e aspectos da vegetação. In RODRIGUES, RR. and BONONI, VLR. (Orgs.). Diretrizes para Conservação e Restauração da Biodiversidade no Estado de São Paulo. São Paulo: Instituto de Botânica. 246 p. 
NIMER, E. 1989. Climatologia do Brasil. Rio de Janeiro: Secretaria de Planejamento e Coordenação da Presidência da República, IBGE. 421 p.

OBERDORFF, T. and HUGHES, RM. 1992. Modification of an Index of Biotic Integrity based on fish assemblages to characterize rivers of the Seine Basin, France. Hydrobiologia, vol. 228, no. 2, p. 117-130. http://dx.doi.org/10.1007/BF00006200

PINTO, BCT., ARAÚJO, FG. and HUGHES, RM. 2006. Effects of landscape and riparian condition on a fish index of biotic integrity in a large southeastern Brazil river. Hydrobiologia, vol. 556, no. 1, p. 69-83. http://dx.doi.org/10.1007/s10750005-9009-y

PLAFKIN, JL., BARBOUR, MT., PORTER, KD., GROSS, SK. and HUGHES, RM. 1989. Rapid bioassessment protocols for use in streams and rivers: Benthic macroinvertebrates and fish. Washington: U.S. Environmental Protection Agency, Office of Water Regulations and Standards. EPA 440-4-89001.

PUSEY, BJ., KENNARD, MJ., ARTHUR, JM. and ARTHINGTON, AH. 1998. Quantitative sampling of stream fish assemblages: single vs multiple-pass electrofishing. Australian Journal of Ecology, vol. 23, no. 4, p. 365-374. http://dx.doi. org/10.1111/j.1442-9993.1998.tb00741.x

ROSET, N., GRENOUILlET, G., GOFFAUX, D., PONT, D. and KESTMONT, P. 2007. A review of existing fish assemblage indicators and methodologies. Fisheries Management and Ecology, vol. 14, no. 6, p. 393-405. http://dx.doi. org/10.1111/j.1365-2400.2007.00589.x

ROTH, NE., SOUTHERLAND, MT., MERCURIO, G., CHAILLOU, JC., KAZYAK, PF., STRANKO, SS., PROCHASKA, AP., HEIMBUCH, DG. and SEIBEL, JC. 1999. State of the Streams: 1995-1997 Maryland biological stream survey results. Annapolis: Versar Inc. for Maryland Department of Natural Resources, Monitoring and Non-Tidal Assessment Division. CBWP-MANTA-EA-99-6.

ROTH, NE., SOUTHERLAND, MT., CHAILLOU, JC., KAZYAK, PF. and STRANKO, SA. 2000.
Refinement and validation of a fish index of biotic integrity for Maryland streams. Annapolis: Versar Inc. for Maryland Department of Natural Resources, Monitoring and Non-Tidal Assessment Division. CBWP-MANTA-EA-00-2.

SCHLEIGER, SL. 2000. Use of an index of biotic integrity to detect effects of land uses on stream fish communities in West-Central Georgia. Transactions of the American Fishery Society, vol. 129, no. 5, p. 1118-1133. http://dx.doi.org/10.1577/1548$8659(2000) 129<1118: \mathrm{UOAIOB}>2.0 . \mathrm{CO} ; 2$

SILVA, AM., CASATTI, L., ÁlVARES, CA., LEITE, AM., MARTINELLI, LA. and DURRANT, SF. 2007. Soil loss and habitat quality in streams of a meso-scale river basin. Scientia Agricola, vol. 64, no. 4, p. 336-343. http://dx.doi.org/10.1590/S010390162007000400004

TEJERINA-GARRO, FL., MALDONADO, M., IBANEEZ, C., PONT, D., ROSET, N. and OBERDORFF, T. 2005. Effects of natural and anthropogenic environmental changes on riverine fish assemblages: a framework for ecological assessment of rivers. Brazilian Archives of Biology and Technology, vol. 48, no. 1, p. 91-108. http://dx.doi.org/10.1590/ S1516-89132005000100013

TERESA, FB. and CASATTI, L. 2010. Importância da vegetação ripária em região intensamente desmatada no sudeste do Brasil: um estudo com peixes de riacho. Pan American Journal of Aquatic Sciences, vol. 5, n. 3, p. 444-453. Available from <http://www.panamjas.org/pdf_artigos/ PANAMJAS_5\%283\%29_444-453.pdf>

TERESA, FB. and CASATTI, L. 2012. Influence of forest cover and mesohabitat types on functional and taxonomic diversity of fish communities in Neotropical lowland streams. Ecology of Freshwater Fish, vol. 21, no. 3, p. 433-442. http://dx.doi. org/10.1111/j.1600-0633.2012.00562.x

ZALEWSKI, M. and COWX, IG. 1990. Factors affecting the efficiency of electric fishing. In COWX, IG. and LAMARQUE, P. (Eds.). Fish with electricity: applications in freshwater fisheries management. Oxford: Fishing New Books. 243 p. 